Portland State University

PDXScholar

\title{
Interactions Among Fuel Management, Species \\ Composition, Bark Beetles, and Climate Change and the Potential Effects on Forests of the Lake Tahoe Basin
}

Robert M. Scheller

Portland State University, rmschell@pdx.edu

Alec M. Kretchun

Portland State University

E. Louise Loudermilk

USDA Forest Service

Matthew D. Hurteau

University of New Mexico

Peter J. Weisberg

University of Nevada Reno Follow this and additional works at: https://pdxscholar.library.pdx.edu/esm_fac

Part of the Environmental Sciences Commons

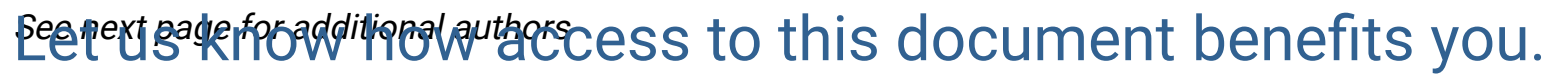

\section{Citation Details}

Scheller, R. M., Kretchun, A. M., Loudermilk, E. L., Hurteau, M. D., Weisberg, P. J., \& Skinner, C. Interactions Among Fuel Management, Species Composition, Bark Beetles, and Climate Change and the Potential Effects on Forests of the Lake Tahoe Basin. Ecosystems, 1-14.

This Article is brought to you for free and open access. It has been accepted for inclusion in Environmental Science and Management Faculty Publications and Presentations by an authorized administrator of PDXScholar. Please contact us if we can make this document more accessible: pdxscholar@pdx.edu. 


\section{Authors}

Robert M. Scheller, Alec M. Kretchun, E. Louise Loudermilk, Matthew D. Hurteau, Peter J. Weisberg, and Carl Skinner 


\title{
Interactions Among Fuel Management, Species Composition, Bark Beetles, and Climate Change and the Potential Effects on Forests of the Lake Tahoe Basin
}

\author{
Robert M. Scheller, ${ }^{1 *}$ Alec M. Kretchun, ${ }^{1}$ E. Louise Loudermilk, ${ }^{2}$ \\ Matthew D. Hurteau, ${ }^{3}$ Peter J. Weisberg, ${ }^{4}$ and Carl Skinner ${ }^{5}$
}

\begin{abstract}
${ }^{1}$ Portland State University, P.O. Box 751, Portland, Oregon 97201, USA; ${ }^{2}$ USDA Forest Service, Forestry Sciences Laboratory, 320 Green St., Athens, Georgia 30602, USA; ${ }^{3}$ University of New Mexico, Albuquerque, New Mexico 87131, USA; ${ }^{4}$ University of NevadaReno, 1664 N Virginia St., Reno, Nevada 89503, USA; ${ }^{5}$ USDA Forest Service Pacific Southwest Research Station, Redding, California,

\begin{abstract}
Climate-driven increases in wildfires, drought conditions, and insect outbreaks are critical threats to forest carbon stores. In particular, bark beetles are important disturbance agents although their longterm interactions with future climate change are poorly understood. Droughts and the associated moisture deficit contribute to the onset of bark beetle outbreaks although outbreak extent and severity is dependent upon the density of host trees, wildfire, and forest management. Our objective was to estimate the effects of climate change and bark beetle outbreaks on ecosystem carbon dynamics over the next century in a western US forest. Specifically, we hypothesized that (a) bark beetle outbreaks under climate change would reduce net ecosystem carbon balance (NECB) and increase
\end{abstract}

Received 1 September 2016; accepted 4 July 2017

Author contributions RS: Conceived of or designed study, Performed research, Analyzed data, Contributed new methods or models, Wrote the paper; AK: Performed research, Analyzed data, Wrote the paper; LL: Conceived of or designed study, Performed research; MH: Conceived of or designed study, Wrote the paper; PW: Conceived of or designed study; CS: Conceived of or designed study.

*Corresponding author; e-mail: rschell@ncsu.edu uncertainty and (b) these effects could be ameliorated by fuels management. We also examined the specific tree species dynamics-competition and release-that determined NECB response to bark beetle outbreaks. Our study area was the Lake Tahoe Basin (LTB), CA and NV, USA, an area of diverse forest types encompassing steep elevation and climatic gradients and representative of mixed-conifer forests throughout the western United States. We simulated climate change, bark beetles, wildfire, and fuels management using a landscape-scale stochastic model of disturbance and succession. We simulated the period 2010-2100 using downscaled climate projections. Recurring droughts generated conditions conducive to large-scale outbreaks; the resulting large and sustained outbreaks significantly increased the probability of LTB forests becoming C sources over decadal time scales, with slower-than-anticipated landscape-scale recovery. Tree species composition was substantially altered with a reduction in functional redundancy and productivity. Results indicate heightened uncertainty due to the synergistic influences of climate change and interacting disturbances. Our results further indicate that current fuel management practices will not be effective at reducing landscape-scale outbreak mortality. Our results pro- 
vide critical insights into the interaction of drivers (bark beetles, wildfire, fuel management) that increase the risk of $\mathrm{C}$ loss and shifting community composition if bark beetle outbreaks become more frequent.
Key words: net ecosystem carbon balance; bark beetles; wildfire; fuels management; climate change; Lake Tahoe Basin.

\section{INTRODUCTION}

Climate change will alter forest carbon dynamics with the direction and magnitude of change varying geographically. In the western USA, widespread increases in tree mortality in recent decades have been linked to regional warming and drought (van Mantgem and others 2009). Changing climate has also been identified as a contributing factor to increased large wildfire frequency and insect outbreaks (Kurz and others 2008; Meddens and others 2012; Edburg and others 2012; Williams and others 2014; Ghimire and others 2015; Westerling 2016). Wildfire, drought, and insect outbreaks can cause substantial tree mortality and can temporarily shift forests from being net $\mathrm{C}$ sinks to net $\mathrm{C}$ sources (Campbell and others 2007; Kurz and others 2008; Amiro and others 2010; Hicke and others 2012a, b). These trends are expected to increase with projected climate change in part due to anticipated reductions in snowpack recharge of soil moisture and increasing vapor pressure deficit (Coats and others 2013; Williams and others 2013). Drought increases wildfire activity and insect outbreaks, and the frequency, size, and severity of both disturbances are projected to increase with changing climate (Mattson and Haack 1987; Westerling and others 2006, 2011; Ward and Masters 2007; Miller and others 2009). The interactions among climate change, insects, drought, and wildfire will create novel emergent landscape patterns and increase uncertainty about future conditions, including carbon storage capacity (Peterson and others 2014; Williams and others 2016).

Bark beetles (Coleoptera: Curculionidae, Scolytinae) are native to the western USA and have historically played a key ecological role by reducing forest density and contributing to stand structural heterogeneity. In recent decades, however, bark beetle populations have erupted due to several concurrent forest and climatic conditions: increased host availability and suitability (Raffa and others 2008), weather including drought, longer and warmer summers, reduced winter mortality, and cyclical population dynamics (Raffa and others 2008; Klutsch and others 2009; Negron and others 2009; Creeden and others 2014). This has caused high levels of conifer mortality across many landscapes, including managed areas of the western USA (Hicke and others 2012a, b).

There is a significant link between bark beetle outbreaks and periods of severe drought (Kretchun and others 2016), in part due to their temperature dependence (Aukema and others 2008; Raffa and others 2008; Bentz and others 2010) and also because soil moisture deficits reduce tree resin production and may cause terpene imbalances (Mattson and Haack 1987), making conifers more susceptible to beetle infestation; other climatic factors are also important (Creeden and others 2014). Bark beetle-caused mortality has been positively correlated with drought and negatively correlated with spring soil moisture availability in Yosemite NP (Guarín and Taylor 2005). Recent trends in temperature and precipitation have increased the frequency and length of periodic outbreaks. Generally, beetle activity is expected to increase given future climate scenarios, though individual bark beetle response will vary, depending on host availability and spatial configuration (Hicke and others 2006; Bentz and others 2010).

Host availability is determined by landscape history including past disturbances and management activity. In areas where fire has been suppressed for long periods, host availability may be particularly high (Jenkins and others 2008). Regions with high tree densities and therefore high resource competition are particularly susceptible to drought stress and subsequent beetle attack (Negrón and Popp 2004). Conversely, management activities that are designed to reduce fire-risk and severity (Stephens and others 2009), to store C (Hurteau and others 2008; Loudermilk and others 2016), or otherwise reduce tree density (Egan and others 2010) could impede a bark beetle outbreak and reduce the risk of bark beetle-caused mortality (Fettig and others 2007). These activities typically reduce crown density, increase canopy diversity, and reduce water stress during drought (Hood and others 2016).

Our objective was to estimate the effects of bark beetle outbreaks given a changing climate with increased drought and changing host density as a function of wildfire and management efforts to 
reduce wildfire. Climate influences beetle outbreaks through temperature effects on winter survival and development rates and drought effects on host trees. We modeled the onset of outbreaks only as a function of drought, acknowledging that this does not capture the full impact of climate change on outbreaks (Creeden and others 2014). We used net ecosystem carbon balance (NECB) as our primary response variable to summarize net $C$ change across the landscape because it integrates most $\mathrm{C}$ fluxes into and out of a system, including growth, disturbances, and soil accumulation or respiration (Chapin III and others 2006; Smithwick and others 2007). Specifically, we hypothesized that bark beetle outbreaks under climate change would reduce NECB and increase variability over time. Further, we hypothesized that fuels management could effectively reduce bark beetle-caused mortality, increase NECB, and reduce variability (Fettig and others 2007; Egan and others 2010; Hood and others 2016). We also examined the specific tree species dynamics that determined NECB trajectories following bark beetle outbreaks.

\section{Methods}

\section{Study Area}

We focused on the forests of the Lake Tahoe Basin (LTB), California and Nevada, USA, because of the extensive empirical data collected and the strong link between beetle outbreaks and drought in the region (Guarín and Taylor 2005). We have previously simulated wildfire and forest growth response to climate change, wildfire, and fuels management (Loudermilk and others 2013, 2014) and the effects of drought and bark beetles on forest growth (Kretchun and others 2016) in the LTB. The LTB comprises approximately 85,000 ha of forested land that surrounds Lake Tahoe. The climate of the Basin is characteristically montane Mediterranean, with winter storms and dry summers with $5-10 \%$ of precipitation from summer thunderstorms. The hydrology of the system is snow-driven (50$150 \mathrm{~cm}$ annually), with spring snowmelt providing a majority of the soil moisture recharge. Snowpack persists at high elevation year round. Mean daily temperatures range from -6 to $24^{\circ} \mathrm{C}$, with a mean annual temperature of $5^{\circ} \mathrm{C}$ (Coats 2010). The forested area of the LTB is predominantly $(78 \%)$ managed by the USDA Forest Service.

Forests of the LTB consist primarily of mixedconifer stands and vary in composition and structure as a function of elevation, soils, and topography. Jeffrey pine (Pinus jeffreyi) and white fir (Abies concolor) dominate, with interspersed sugar pine $(P$. lambertiana), at lower elevations; red fir (A. magnifica), western white pine ( $P$. monticola), and lodgepole pine $(P$. contorta) dominate in upper montane and subalpine areas (Table 1). Understory regeneration is dominated by white fir. The basin was heavily logged from the 1880s to the turn of the twentieth century, with approximately $60 \%$ of the forest clear-cut for use in nearby silver mining operations (Taylor 2004). Natural regeneration and fire suppression beginning in the early twentieth century have produced dense forests with tree age classes dominated by younger individuals $(<120$ years) and with increasing spatial extent of more shade-tolerant species (for example, white fir) (Nagel and Taylor 2005). Due to this landscape legacy and continued fire suppression, forest $\mathrm{C}$ has the potential to continue increasing into the coming century (Loudermilk and others 2013).

Several species of bark beetles, including the Jeffrey Pine Beetle ('JPB,' Dendroctonus jeffreyi), Mountain Pine Beetle ('MPB,' D. ponderosae), and Fir Engraver Beetle ('FEB,' Scolytus ventralis) are active in the LTB. Although they share many life history strategies, each beetle species has a unique preferred host. For instance, JPB is an obligate insect of Jeffrey pine while FEB infests subalpine species like red and white fir. MPB shows the least specificity in hosts and attacks several pine species including ponderosa pine, lodgepole pine, and sugar pine. Annual damage up to 14,000 ha from 1993 to 2013 of forested land in the LTB has been recorded and attributed to one or more of these bark beetles (USDA Forest Service Pacific Southwest Region. 2013. Region 5 Aerial Detection Monitoring. http://www.fs.usda.gov/detail/r5/for est-grasslandhealth/?cid=fsbdev3_046696).

\section{Modeling Framework}

Projecting the consequences of climate change, multiple interacting disturbances, and management requires a sufficiently detailed modeling framework that is validated for landscape $C$ and disturbance dynamics; we used the spatially explicit forest landscape and disturbance model, LANDIS-II (Mladenoff 2004; Scheller and others 2007). LANDIS-II simulates succession, disturbance, and management over large spatial extents and extended time periods, emphasizing spatial interactions among these processes. Trees and shrubs are modeled as species-age cohorts; each species has its own unique life history attributes and as such, each responds uniquely to disturbance. Every cell across the landscape has a unique combination of cohorts, 
Table 1. Major Tree Species Used in LANDIS-II Modeling of the Lake Tahoe Basin, CA, NV, USA. Adapted from Loudermilk and others (2014)

\begin{tabular}{llllll}
\hline Tree species & $\begin{array}{l}\text { Longevity } \\
\text { (years) }\end{array}$ & $\begin{array}{l}\text { Age of sexual } \\
\text { maturity (years) }\end{array}$ & $\begin{array}{l}\text { Shade } \\
\text { tolerance (1-5) }\end{array}$ & $\begin{array}{l}\text { Fire tolerance } \\
(1-5)\end{array}$ & $\begin{array}{l}\text { Post-fire } \\
\text { reprouting ability }\end{array}$ \\
\hline Pinus jeffreyi & 500 & 25 & 2 & 5 & $\mathrm{~N}$ \\
Pinus lambertiana & 550 & 20 & 3 & 5 & $\mathrm{~N}$ \\
Calocedrus decurrens & 500 & 30 & 4 & 5 & $\mathrm{~N}$ \\
Abies concolor & 450 & 35 & 4 & 3 & $\mathrm{~N}$ \\
Abies magnifica & 500 & 40 & 3 & 4 & $\mathrm{~N}$ \\
Pinus contorta & 250 & 7 & 1 & 2 & $\mathrm{~N}$ \\
Pinus monticola & 550 & 18 & 3 & 4 & $\mathrm{~N}$ \\
Tsuga mertensiana & 800 & 20 & 5 & 1 & $\mathrm{~N}$ \\
Pinus albicaulis & 900 & 30 & 3 & 2 & $\mathrm{Y}$ \\
Populus tremuloides & 175 & 15 & 1 & 2 & \multicolumn{2}{c}{} \\
\hline
\end{tabular}

live biomass, dead material, and soils as determined by its simulated history of succession, disturbance, and management.

We simulated succession, bark beetle dynamics, wildfire, and fuels management. C cycling was incorporated in all modeled processes including forest disturbances (for example, pyrolysis), allowing for calculation of net ecosystem $\mathrm{C}$ balance (NECB) and C storage (Loudermilk and others 2016) (Figure 1). All simulations were run with a 1 ha spatial resolution.

\section{Succession and C Dynamics}

Landscape C dynamics were simulated using the Century Succession extension ('Century') for LANDIS-II (Scheller and others 2011). Century

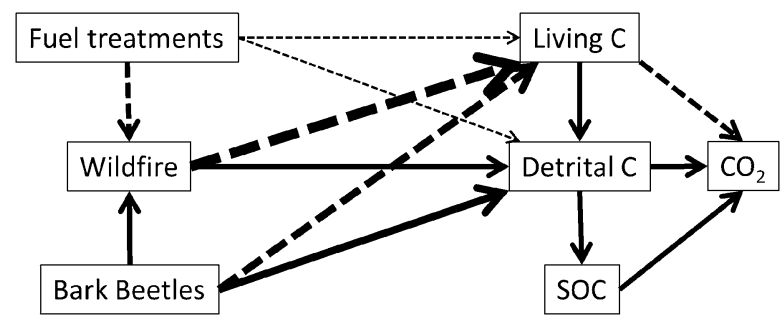

Figure 1. Conceptual diagram of the primary effects of bark beetles, fuel treatments (forest thinning and prescribed fire), and wildfire on the three primary landscape C pools. Solid lines indicate positive effects, dashed lines negative effects, and line thickness indicates expected strength of the effect. Bark beetles reduce living $\mathrm{C}$ and increase detrital C. Fuel treatments reduce wildfire, living $\mathrm{C}$, and detrital $\mathrm{C}$. Wildfire reduces living $\mathrm{C}$ although increasing detrital C. Bark beetles, fuel treatments, and wildfire have no direct effects on SOC. Because fuel treatments reduce wildfire, mortality of living $\mathrm{C}$ is substantially reduced. Living $\mathrm{C}$ captures $\mathrm{CO}_{2}$; detrital $\mathrm{C}$ and SOC release $\mathrm{CO}_{2}$ to the atmosphere via heterotrophic respiration. Adapted from Loudermilk and others (2016). simulates both above- and belowground processes, including net primary productivity (a function of cohort age, competition, climate, and available water and nutrients), regeneration (Scheller and others 2011), and $\mathrm{C}$ and $\mathrm{N}$ allocation (Lucash and others 2014). Wood and litter deposition and decomposition, soil accumulation and decomposition, and available soil moisture are derived from the CENTURY soils model (Parton and others 1983, 1994; Scheller and others 2011). Species parameters as well as calibration and validation procedures are detailed in Loudermilk and others (2013) and Kretchun and others (2016) (archived at https:// github.com/LANDIS-II-Foundation/Project-LakeTahoe-Basin-2010).

Estimated soil water availability is critical for understanding potential drought effects and within Century is determined by precipitation, soil water holding capacity, and evapotranspiration. Cohorts compete for water (in addition to light and nitrogen), and growth is restricted when water availability is low; low available water further prevents establishment when drought conditions persist for a sufficiently high percentage of the growing period. Sensitivity of growth to drought was validated using tree ring data (Kretchun and others 2016).

Century validation included net ecosystem production, aboveground live biomass (by species), soil organic carbon, and soil inorganic nitrogen (Loudermilk and others 2013). For example, mean simulated aboveground initial live biomass following model spin-up $\left(10,006 \mathrm{~g} \mathrm{~m}^{-2}\right)$ was validated with an independent dataset $\left(10,787 \mathrm{~g} \mathrm{~m}^{-2}\right)$ measured from remote sensing (Dobrowski and others 2005; Loudermilk and others 2013). Kretchun and others (2016) compared tree ring estimates of aboveground net primary productivity (ANPP) of Abies concolor, Abies magnifica, Calocedrus decurrens, 
Pinus jeffreyi, Pinus contorta, and Pinus lambertiana to simulated ANPP with and without bark beetles; they demonstrated that simulated ANPP was sufficiently correlated with tree ring estimates, was sensitive to both climate and disturbance, and was most accurate when bark beetles were explicitly simulated.

\section{Bark Beetle Dynamics}

We simulated three bark beetle species (JPB, MPB, and FEB) that cause the majority of insect mortality in the LTB. For many bark beetle species, climate influences outbreaks in three ways: low winter temperatures cause beetle mortality; year-round temperatures influence development and mass attack; and drought stress reduces host resistance (Creeden and others 2014). Here, we model climate influences as a function of drought and host density alone, recognizing that the full suite of climatic influences are necessary for a fully mechanistic model.

Bark beetle outbreaks (mortality that exceeds background mortality, which was captured in the Century extension) were modeled using the Biological Disturbance Agent (BDA) extension (Sturtevant and others 2004). This extension simulates tree mortality from insect outbreaks and can represent multiple insects simultaneously. The BDA assigns insect-specific resource requirements and tree species-specific vulnerability that varies by cohort age (Table 2). Within BDA, sites are probabilistically selected for disturbance based upon the host density at a given site; non-hosts reduce site disturbance probability. Disturbance probability therefore is an emergent property of host density that can be altered by other mortality agents, including wildfire and fuels management. Cohort mortality at an outbreak site is subsequently determined by species' age and host susceptibility probabilities (Table 2 ). The susceptibility of each cohort to insect mortality was derived from empirical field studies and expert opinion (Kretchun and others 2016) (Table 2). Following mortality, dead biomass remains on site and was either added to the downed woody debris $\mathrm{C}$ pool or the fine woody debris $\mathrm{C}$ pool.

Drought conditions can stress and weaken trees thus making them more susceptible to insect attack (Creeden and others 2014). Understanding climateand landscape-synchronous outbreaks, however, requires quantifying the temporal relationship between the onset of drought and increased incidence of tree mortality via bark beetles (Guarín and Taylor 2005; Hebertson and Jenkins 2008). To
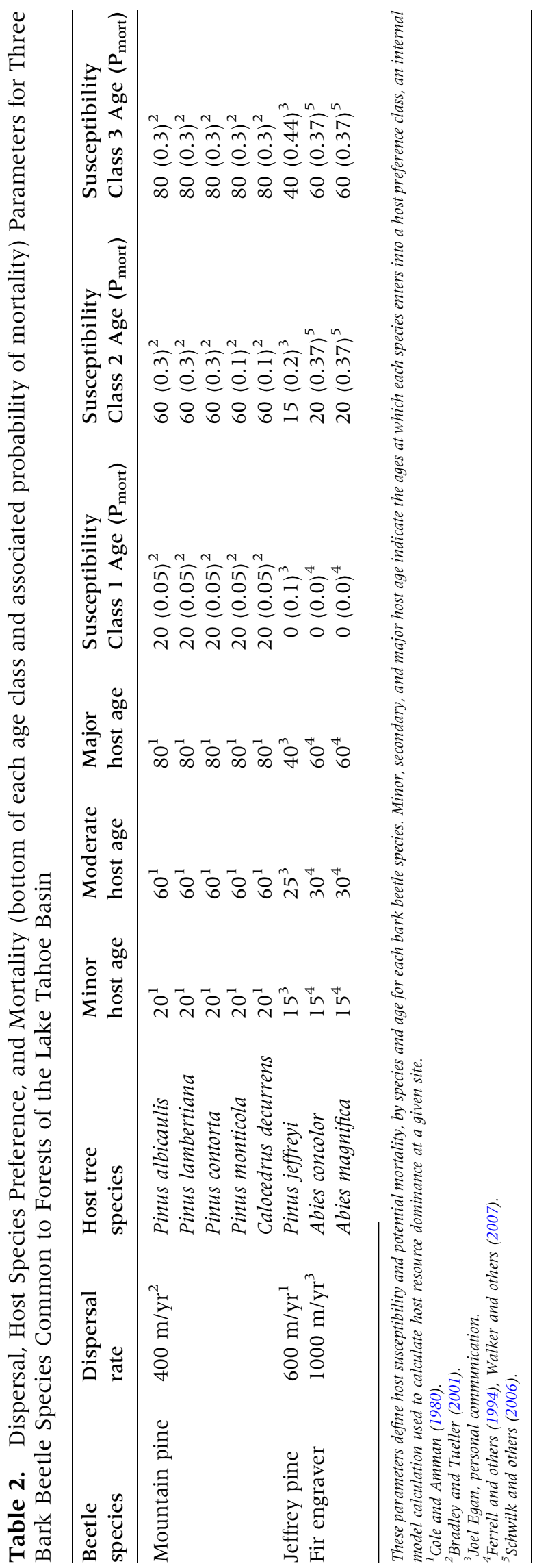
create this relationship within the BDA extension, the Palmer Drought Severity Index (PDSI) (Palmer 1965) was used to determine the onset of drought events; several empirical studies demonstrate epidemic beetle outbreaks lagging several years behind the onset of a drought period (Guarín and Taylor 2005; Egan and others 2016). Following Guarín and Taylor (2005), annual PDSI values less than -2.0 for two or more years determined the initiation of simulated beetle outbreaks. Outbreak duration was calibrated from empirical data: average outbreak length in the basin is 5 years and simulated durations were randomly selected between 3 and 7 years (Egan and others 2016). As an outbreak progresses and resources are consumed, annual bark beetle mortality declines.

We calibrated our simulated outbreaks to approximate the spatial extent and pattern observed in aerial detection survey maps within the LTB using data from 1993 to 2013, produced by the US Forest Service (Kretchun and others 2016). We further assumed that the peak years on record for each bark beetle represent an 'outbreak' period and used a reference historical climate period (19862006) for calibration. This reference period was chosen because it captured a variety of climatic conditions and was the only beetle outbreak in the LTB to have been recorded with flyover mapping by USFS Forest Health Staff.

Outbreaks were calibrated to match the cumulative area-affected targets by adjusting the number of beetle 'epicenters' (initial outbreak sites, probabilistically chosen based on host density). Calibration to this reference period successfully matched cumulative area affected $( \pm 20 \%$ of total beetle outbreak area), reductions to landscape-scale forest growth (Kretchun and others 2016), as well the spatial patterning of individual beetle species damage (Beverly M. Bulaon, personal communication).

\section{Wildfire}

Wildfire was modeled using the Dynamic Fire and Fuels Extension ('DFFS'), which simulates fire spread, severity, and effects based on ignitions, fuels, weather conditions, slope, and topography (Sturtevant and others 2009). The LTB was divided into three fire regions based on variation in fire regimes and the expected number of ignitions per year (an average of three ignitions per year) (Loudermilk and others 2013). Recent fire size and occurrence records (1995-2007) were used to calibrate a target fire size distribution using contemporary climate conditions (see Loudermilk and others 2013) and therefore implicitly includes fire suppression. A key assumption is that calibration against contemporary fire records will allow a novel fire regime to emerge, given changing climate and fuel conditions. Simulated fire sizes were a function of fire weather and fuel conditions, for example, fine fuel moisture and fuel availability within each fire region. Fuels type classifications were similar to those previously developed for the southern Sierra Nevada (Syphard and others 2011; see Table S6 Loudermilk and others 2013). We also included a 'Special Dead Fuels' class to capture dead biomass dynamics if trees were killed by bark beetles. Following beetle mortality, dead conifer cohorts are tracked and contribute to the dead conifer index, which alters spread rate and mimics the ladder fuel effects of dead biomass in the understory. Within the Dynamic Fuel System, a conifer fuel type combined with a dead conifer index greater than 0 , is automatically converted to a fuels class with higher spread rates and severity resulting from the large amounts of dead conifer trees and litter. This Special Dead Fuels type is based on the M-3 (dead balsam fir) fuel type within the Canadian Forest Fire Behavior Prediction System (Forestry Canada Fire Danger Group 1992). The Special Dead Fuels transitions to another fuel type after 5 years, assuming that fine fuels have substantially decayed. However, there was insufficient empirical data to validate our estimates of post-outbreak changes to fire behavior. Nor did we expect simulated fire to be sensitive to bark beetlegenerated fuel (Hicke and others 2012a, b; Harvey and others 2014) and simulated wildfire infrequently intersected bark beetle-generated fuel (Lynch and others 2006; Hicke and others 2012a, b; Harvey and others 2014). Wildfire mortality is a function of species' fire tolerance (Table 1), cohort age (young cohorts are more susceptible), and simulated fire intensity (Sturtevant and others 2009).

\section{Management}

Concurrent with bark beetles and wildfires, we simulated the continuation of fuel treatments as they have been applied over the past 20 years; fuel treatments were developed and calibrated from planning documents and expert knowledge and included input from federal, state, and local agencies (Loudermilk and others 2014). In the LTB, fuel management is a combination of thinning smaller diameter trees followed by prescribed fire with the goal of reducing wildfire spread and severity. Our fuel treatment design was developed from work- 
shops with LTB forest managers and designed to emulate as closely as possible the fuel management objectives for the area. Specifically, we simulated the removal of young conifers, preferentially targeting white fir, accompanied by fine fuels reduction (Loudermilk and others 2014, 2016). Fuel treatments removed trees less than $35.6 \mathrm{~cm}, 85 \%$ of downed woody debris, and $95 \%$ of litter at a 15 year rotation interval $(6.7 \%$ of the LTB per year) (Loudermilk and others 2014). Following treatment, fuel types were modified to reflect treatment effects including less downed woody debris and fine fuels and a lower probability of ignition (Loudermilk and others 2014). Fuel treatments were applied in three concentric zones $(58 \%$ of total forested area) around the lake including a 'defensible space' immediately adjacent to existing urban areas, a 'defense zone' 0.4 -km buffer from the defensible space, and an 'extended wildlandurban interface' that incorporates areas near roads and dispersed housing. Thinning was restricted to slopes less than $30 \%$. Fuel treatments targeted stands with the greatest concentration of 'ladder fuels' (young shade-tolerant conifers) and thinning removed the youngest cohorts with preferential removal of more shade-tolerant and fire-sensitive species, particularly white fir (Loudermilk and others 2014). If bark beetle-caused mortality-removed ladder fuels-notably white firs at least 20 years of age are susceptible to FEB during an outbreak (Table 2)-the stand was less likely to be treated. Full details on thinning prescriptions, calibration, and implementation are in Loudermilk and others (2014).

\section{Scenarios}

We simulated a total of eight scenarios, combining two climate trajectories ('baseline' and 'high emissions'), two bark beetle options (including and excluding bark beetles), and two fuel management scenarios (with and without). The 'baseline' climate scenario represents the 30-year normal (1971-2000) climate from PRISM [Parameter-elevation Regressions on Independent Slopes Model, http://www.prism.oregonstate.edu/] with random annual selection from this period. The high emissions' climate projection for the LTB was developed from downscaled Geophysical Fluid Dynamics Laboratory projections, assuming high fossil fuel emissions (Coats 2010) (see Loudermilk and others 2013, 2014 for details). Projected temperatures rose steadily over the 90 -year period, with mean maximum summer temperature increasing by $6.4^{\circ} \mathrm{C}$ and mean minimum winter temperature increasing

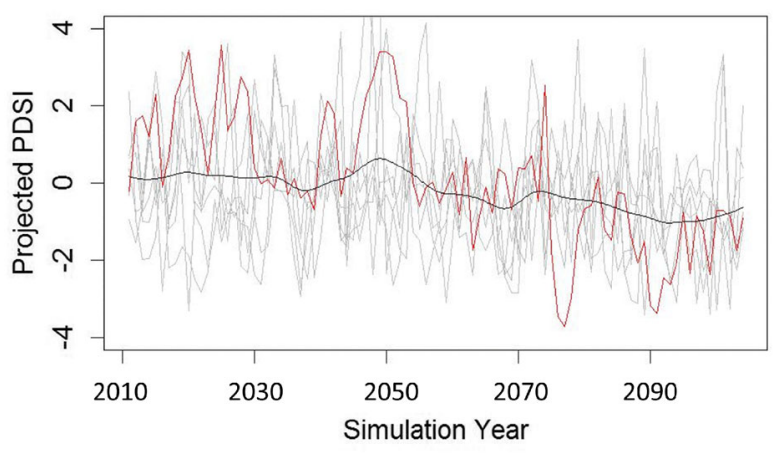

Figure 2. Palmer Drought Severity Index (PDSI) from downscaled Geophysical Fluid Dynamics Laboratory climate projections, assuming high fossil fuel emissions, for the Lake Tahoe Basin (solid red line). Additional PDSI projections (gray lines) from high fossil fuel emissions scenarios for the following GCMs: BNU, Can-ESM, FGOALS G2, GFDL CM3, GISS E2, MiROC. Five-year moving average of all PDSI estimates (solid black line).

by $3.5^{\circ} \mathrm{C}$. Projected precipitation generally declined, but was highly variable from year to year. To determine whether our drought scenarios were reasonable, we estimated PDSI for a suite of highemission GCMs and found similar patterns to those estimated by the GFDL GCM (Figure 2).

Each scenario ran from years 2010-2110 and was replicated five times to capture stochastic variation in wildfire (due to stochastic ignition locations and timing), bark beetles (due to stochastic initiation locations), management (due to probabilistic selection of stands to treat), and regeneration (due to probabilistic seed dispersal and establishment).

\section{Analysis}

We used log odds ratio (LOR) to determine the likelihood of the landscape switching from a net $\mathrm{C}$ sink to a net $\mathrm{C}$ source in any given year for each quarter century when comparing scenarios with and without bark beetles; a higher value indicates an increase in the likelihood of becoming a C source due to the inclusion of bark beetles. To examine fuel treatments effects, the log odds ratio was determined separately for simulations with and without fuel treatments. Log odds ratios were estimated using the 'odds.ratio' function within the 'abd' package in $\mathrm{R}$, which calculates log odds ratios and confidence intervals based on a $2 \times 2$ contingency table of treatment levels. In our analysis, the two treatment levels were 'bark beetles/no bark beetles' for simulations with and without fuel treatments, assuming climate change. 


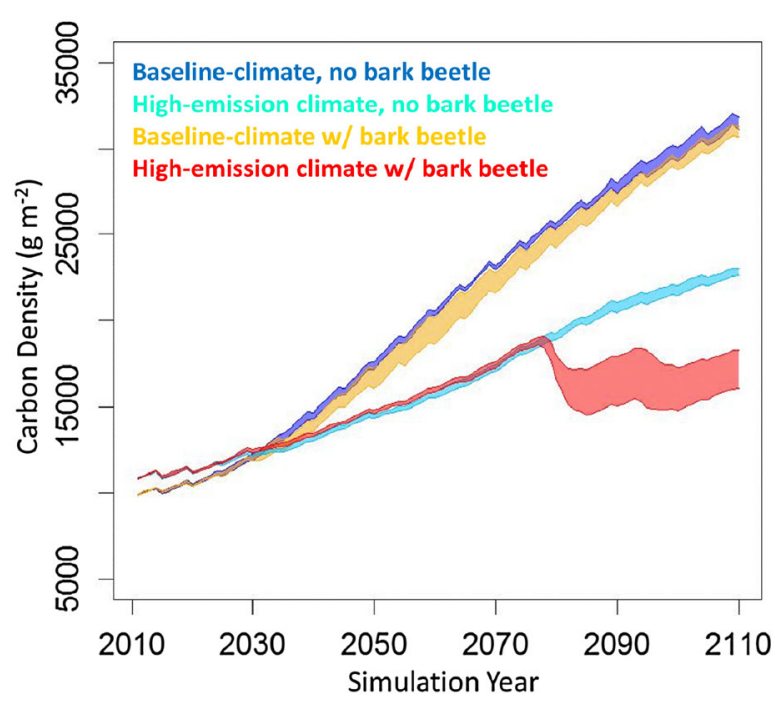

Figure 3. Mean $\mathrm{C}$ density across the Lake Tahoe Basin landscape $\left(\mathrm{g} \mathrm{C} \mathrm{m}^{-2}\right)$ for two climates (baseline, representing the mean climate from 1971 to 2000 and high emissions climate derived from GFDL high fossil fuel emissions). The blue envelope represents baseline climate without bark beetles; cyan represents high emission without bark beetles; yellow represents baseline climate with bark beetles included; red represents high emissions with bark beetles included. All scenarios included wildfire and fuels management and represent the range from five replicates.

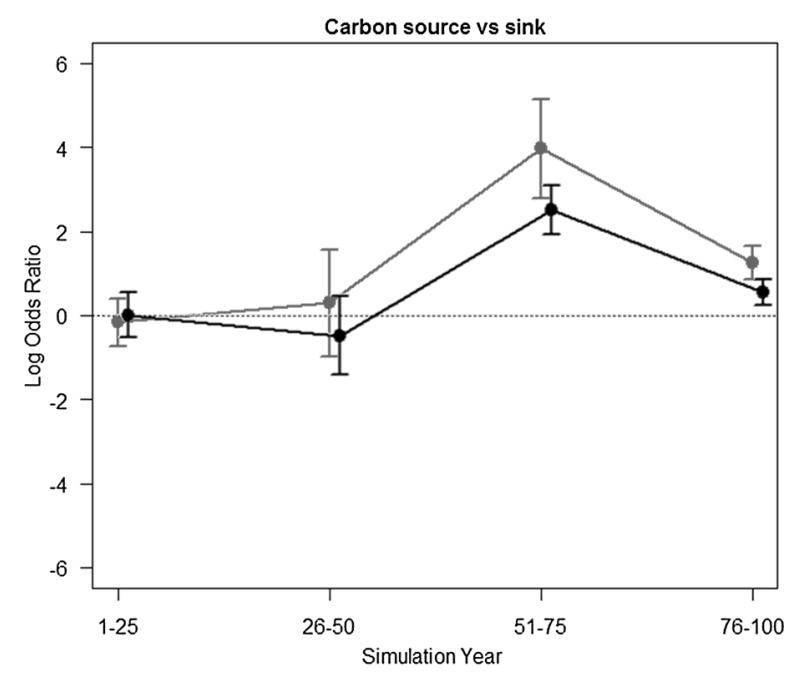

Figure 5. Log odds ratio for net ecosystem carbon balance under high $\mathrm{C}$ emissions climate, including wildfire and bark beetles. Values above zero indicate increasing likelihood of switching from a net $\mathrm{C}$ sink to a net $\mathrm{C}$ source due to bark beetles in any given year during that particular quarter century. Gray indicates simulation with management; black without management. Error bars are the $90 \%$ confidence intervals.

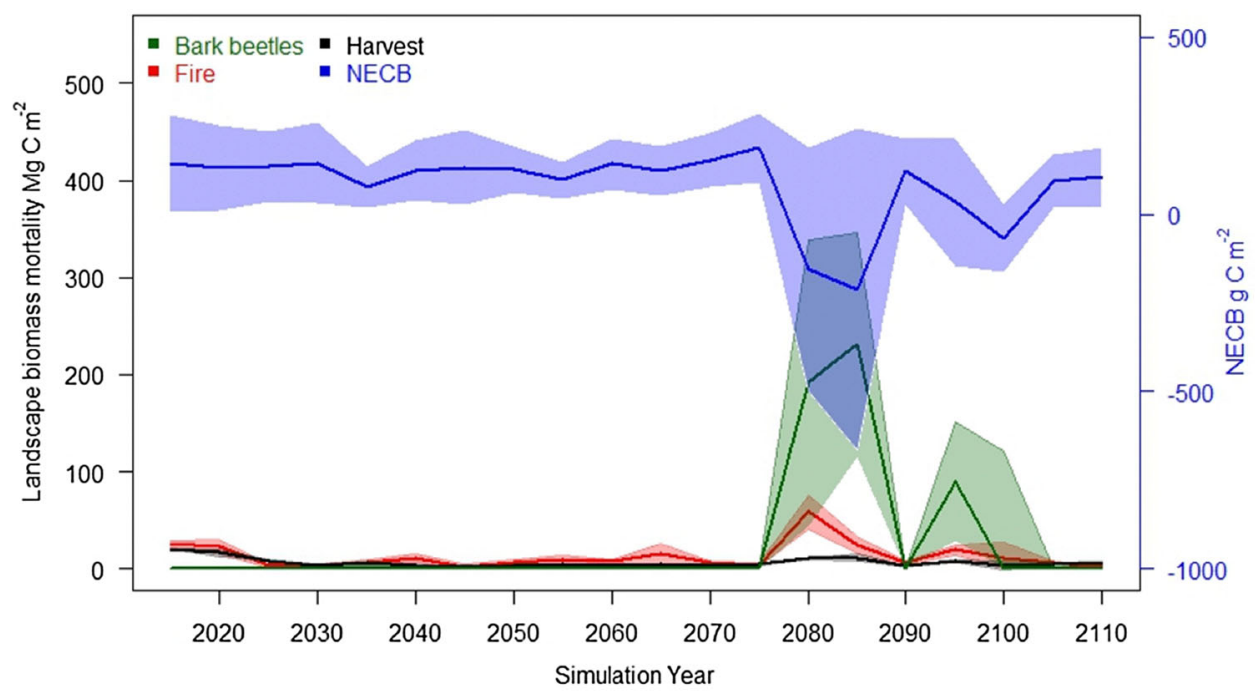

Figure 4. Simulated mean landscape mortality attributed to bark beetles, wildfire, and fuels management (left y-axis) and mean net ecosystem carbon balance (right $\mathrm{y}$ axis), assuming high $\mathrm{C}$ emissions climate. Envelopes surrounding each line represent 90/10 confidence intervals from 5 model replicates.

To estimate whether there was an interaction between bark beetle outbreaks and wildfire, we conducted an ANOVA of total area burned (ha) across all replicates.

\section{RESUltS}

Simulated mean landscape $\mathrm{C}$ density, including above- and belowground live $\mathrm{C}$, detrital $\mathrm{C}$, and soil
C, was strongly affected by the combined effects of climate change and bark beetles (Figure 3). Under the baseline climate scenario (with wildfire and fuel treatments), bark beetles had a minor effect on $C$ density. Under the high emissions scenario, the persistent drought conditions created three large bark beetle outbreaks in the latter half of the century and mean $\mathrm{C}$ density was reduced by approximately $25 \%$ after 2070 (Figure 4). This period also 
corresponded with increased fire although fire mortality was substantially lower than bark beetle mortality (Figure 4). Following the period of intense outbreaks, NECB was reduced on average, although NECB recovered to pre-disturbance levels during the following 25 years (Figure 4).

The probability of LTB forests becoming a net C source to the atmosphere (negative net ecosystem carbon balance), given climate change, was sensitive to bark beetles and fuel management (Figure 5). The odds of switching from a $\mathrm{C}$ sink to a $\mathrm{C}$ source were higher $(>0)$ with bark beetles under high emissions climate change, regardless of whether fuel management was conducted (Figure 5). Simulated bark beetles significantly increased the probability of the landscape becoming a C source, which occurred after the mid-century with climate change (Figure 5). Adding fuels management to the beetle simulations slightly increased the $\log$ odds ratio of converting the forests to a $\mathrm{C}$ source (gray line, Figure 5), that is, the likelihood of forests becoming a net $\mathrm{C}$ source by late-century was higher with fuel management than without when bark beetles are simulated.
The reduction of NECB was due in large part to differential mortality (primarily white fir and Jeffrey pine) and altered host density (Figure 6). Under the high-emissions climate scenario, bark beetles altered the competitive balance between Jeffrey pine and white fir, two dominant species that are the primary focus of fuels management (Figure 6). Within the most heavily managed 'defensible space,' fuel treatments reduced white fir, which reduced competition and allowed Jeffrey pine, to increase, a compensatory mechanism that can maintain overall forest productivity (Loudermilk and others 2014). This compensatory effect diminished outside the defensible space despite the decline of white fir across all management zones (Figure 6). The variation among replicates also increased substantially with the inclusion of bark beetles due to spatial variation in outbreak locations (Figure 6). Insect-caused mortality was not significantly correlated with total area burned $(p=0.19)$ (see also Loudermilk and others 2013).

\section{Discussion}

Bark beetles have the capacity to substantially reduce ecosystem C storage capacity, causing NECB
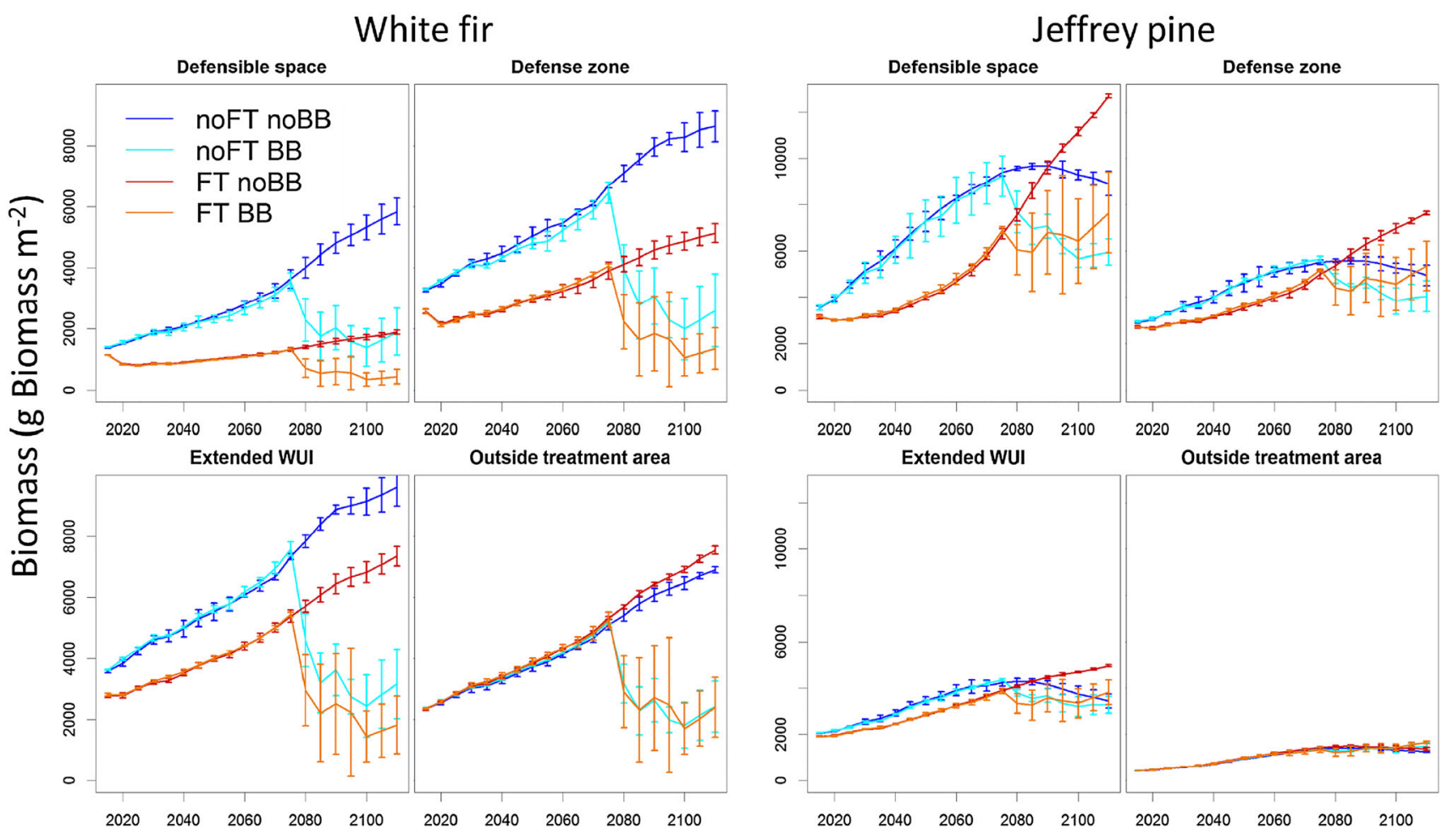

Figure 6. Effect of bark beetles under high emissions climate across four managed zones of the Lake Tahoe Basin on white fir (Abies concolor) and Jeffrey pine (Pinus jeffreyi), represented as mean aboveground live C (g Biomass $\mathrm{m}^{-2}$ ). Dark blue indicates no fuel treatments and no bark beetles; orange indicates no fuel treatments (FT), with bark beetles (BB); cyan indicates fuel treatments with no bark beetles; red indicates bark beetles and fuel treatments. 
to become negative (a $\mathrm{C}$ source) across large areas (Bright and others 2012; Hicke and others 2012a, b; Ghimire and others 2015). Our simulations indicate that the probability of negative NECB will substantially increase over time due to the synergistic influences of bark beetles and climate change. Kurz and others (2008) similarly linked mountain pine beetle outbreaks in British Columbia to negative NECB, although their projections were near term (out to 2020) and did not include an explicit link between climate and insect outbreaks. Our simulations suggest that in the near term, the LTB will remain a strong sink, primarily due to regionalscale forest recovery from extensive clear-cut logging in the late $1800 \mathrm{~s}$, leading to a predominance of dense stands of mature forest that are actively accumulating biomass (Franklin and others 2002; Loudermilk and others 2013). However, there was increased uncertainty in C source-sink projections following drought-induced bark beetle-caused mortality as demonstrated by our $\mathrm{C}$ trajectories and changes in densities of white fir and Jeffrey pine. Earles and others (2014) also found that fir dominated stands subjected to drought and wildfire would exhibit greater $C$ variability. These temporal trends are dependent upon the climate projection and timing of drought events. If outbreaks occurred earlier, we would expect an earlier interruption of NECB trends. Changes in heterotrophic respiration due to climate change contributed minimally to NECB trajectories as higher temperatures were offset by lower soil moisture (Loudermilk and others 2013).

The short-term $(<10$ years or 'gray phase') mechanism by which simulated bark beetles reduced NECB was reduced NPP and increased heterotrophic respiration following canopy mortality (Figure 4) (Edburg and others 2012). Similarly, Bright and others (2013) quantified a short-term reduction in leaf area index and gross primary productivity as a function of bark beetle mortality. Wildfire also contributes to overall mortality and NECB reduction although substantially less than bark beetles as simulated (Figure 4) (see also Hicke and others $2012 \mathrm{a}, \mathrm{b}$ ).

Due to long-term climate change effects, bark beetles caused a longer-term reduction in NECB due to a reduction of compensatory growth (Díaz and others 2007) and productivity (sensu Connell and others 1984). As compared to prior projections of fuels management in the LTB (Loudermilk and others 2014) or insect outbreaks in the New Jersey pine barrens (Kretchun and others 2014) in which the decline of one or two dominant tree species is compensated by release and growth of another, our projections indicate a sustained biomass reduction of two dominant tree species (Figure 6) without immediate replacement by other canopy dominants. Because of several large outbreaks of multiple bark beetle species, both generalists and specialists, bark beetle-caused mortality exceeded the capacity for replacement via regeneration and/ or growth (Figure 4). In our simulations, other extant trees species eventually colonize the broader landscape and compensate for the decline of white fir and Jeffrey pine. For example, there was a substantial increase in Calocedrus decurrens (incensecedar) biomass $(+64.2 \%$ on average) and area occupied increased from $6.1 \%$ of the LTB forested area to $9.6 \%$ at the end of our simulations. Supporting the potential for incense-cedar expansion, Dolanc and others (2014) found large increases in incense-cedar density over the past approximately 90 years across the northern Sierra Nevada, which they attributed to past fire suppression. Thirty-five years after the first severe drought, sufficient canopy replacement occurred and NECB recovered to pre-outbreak levels.

Individual tree susceptibility to bark beetle attack has been found to be higher in some cases after prescribed burns (Bradley and Tueller 2001; Fettig and others 2010). Although individual tree effects were not estimated from this study (due to the cohort structure of the model), our simulations suggest that the increased bark beetle susceptibility due to prescribed burning will be minor considering the limited spatial extent of treatments as compared to the large extent of insect-host availability. Although our model incorporated bark beetle effects on subsequent fuel conditions, interactions between outbreaks and fuels were minor because of the disparate location and timing between wildfires and bark beetle outbreaks, consistent with recent empirical studies (Lynch and others 2006; Hicke and others 2012a, b; Harvey and others 2014).

Over many decades, the spatial distributions of major insects are expected to shift with climate change as the distribution of their preferred hosts shift (Bentz and others 2010). In the near term, there may be a substantial period during which host tree species may be particularly susceptible to drought stress (Bentz and others 2010) and an expansion of niche availability for insects (Ward and Masters 2007). For instance, MPB will likely undergo range expansion due to climatic warming and flexibility in life history strategies, but could become limited to higher elevations in some locations due to limited host availability (Hicke and others 2006; Bentz and others 2010). Over time, 
mortality caused by insects with high host specificity is expected to decline because of reduced host density and increased distance between hosts (Negrón and Popp 2004; Aukema and others 2008), even when drought recurs as simulated (Figures. 2, 4). Although we could not simulate dynamic insect range shifts in this study, there was evidence of reduced insect outbreaks because of reduced host density after year 2070. We found that increased white fir mortality from wildfires in the high emissions climate and the targeting of white fir for treatment reduced white fir density caused a decline in area affected by Fir Engraver.

Fuel management practices in the LTB are implemented primarily as removal of younger conifers and modest forest thinning. Although such fuel management likely improves $C$ retention under some circumstances (Loudermilk and others 2016; North and Hurteau 2011; Hurteau and others 2016), our results suggest there was no C-positive effect (for example, higher NECB) of fuels management when insects are considered (Figure 5). One of the effects of fuel management on fire is a 'shadow' effect whereby localized fuel management reduces fire across the broader landscape (Schmidt and others 2008; Loudermilk and others 2014). Our simulations did not show the same effect of fuel management on insect outbreaks; for example, white fir experienced nearly identical bark beetle-caused mortality across management zones (Figure 6). The principle difference is mode of spread: Insects are not dependent upon a continuous spread surface and can disperse over larger distances. If true, managing for bark beetles may require more aggressive crown thinning to increase the distance between host trees and reduce outbreak severity. Prior studies suggest that thinning can reduce bark beetle mortality (Egan and others 2010; Hood and others 2016), although the potential is dependent on the intensity of thinning, bark beetle species, and the condition prior to thinning (Fettig and others 2007). Outbreaks that reach 'epidemic' levels may nullify the benefits of such preventative measures (Fettig and others 2007). As an example, ponderosa pine plantations in the Modoc National Forest which underwent pre-commercial thinning had significantly lower mortality from a MPB outbreak than untreated plantations; in mixed-conifer stands subject to FEB mortality, thinning had no effect (Egan and others 2010). Hood and others (2016) measured reductions in MPB mortality in low-elevation conifer forests of Montana as a result of fuel treatments and a shift of canopy dominance toward Douglas fir. Our simulations included reduced bark beetle mortality following individual fuel treatments, yet suggest broad ineffectiveness of fuel treatments at reducing bark beetle mortality at the landscapescale, particularly when considering climate change.

Our simulation approach integrated many factors critical to projecting insect outbreaks and landscape $\mathrm{C}$ dynamics over the coming decades, including climate, wildfire, fuel management, and insecthost availability; many of these processes have not previously been combined within a spatially interactive framework in the LTB. There are, however, mechanisms that were not explicitly incorporated. For example, large variation in the timing of MPB outbreaks suggests additional factors were not accounted for by drought and host availability alone (Creeden and others 2014). These may include fine-scale (less than our cell resolution) variation in host damage caused by thinning or prescribed fires (Bradley and Tueller 2001) or wind damage or aspect (Guarín and Taylor 2005). Nor did we evaluate the full life cycle of each beetle population (for example, overwintering mortality) and assumed that PDSI was a sufficient proxy for drought conditions over the spatiotemporal scales of interest. Finally, our simulations are limited by the temporal extent of data available for calibration, particularly bark beetles.

Our results provide critical insights into the interaction of the drivers that generate risk of landscape-scale C loss (> 40\%, Figure 3 ) and can aid in developing broad, strategic approaches to managing forest C. Landscape-scale, strategic management will be particularly important in a changing climate, when higher temperatures will increase drought stress (Coats 2010; Loudermilk and others 2013). Climate adaptive forest health and $\mathrm{C}$ mitigation policies should treat bark beetles, climate change, and wildfire not as independent agents of change, but rather as synergistic change agents to be managed in tandem with a focus on finding opportunities to achieve multiple goals simultaneously.

\section{ACKNOWLEDGMENTS}

This research was funded by a grant from the Sierra Nevada Public Lands Management Act (P086). We are grateful to Jian Yang, Tom Dilts, and Alison Stanton for their contribution to prior efforts that were essential to the research herein. We thank the Lake Tahoe Basin agency personnel at the federal, state, and local level as well as the USDA Forest Service Pacific Southwest Research Station for their support and feedback throughout the project. 
Writing of this paper was supported in part by the Department of Defense, Strategic Environmental Research and Development Program (RC-2243).

\section{REFERENCES}

Amiro BD, Barr AG, Barr JG, Black TA, Bracho R, Brown M, Chen J, Clark KL, Davis KJ, Desai AR, Dore S. 2010. Ecosystem carbon dioxide fluxes after disturbance in forests of North America. J Geophys Res Biogeosci 115:G4.

Aukema BH, Carroll AL, Zheng Y, Zhu J, Raffa KF, Moore RD, Stahl K, Taylor SW. 2008. Movement of outbreak populations of mountain pine beetle: influences of spatiotemporal patterns and climate. Ecography 31:348-58.

Bentz BJ, Régnière J, Fettig CJ, Hansen EM, Hayes JL, Hicke JA, Kelsey RG, Negrón JF, Seybold SJ. 2010. Climate change and bark beetles of the western United States and Canada: direct and indirect effects. Bioscience 60:602-13.

Bradley T, Tueller P. 2001. Effects of fire on bark beetle presence on Jeffrey pine in the Lake Tahoe Basin. For Ecol Manage 142:205-14.

Bright B, Hicke JA, Hudak A. 2012. Landscape-scale analysis of aboveground tree carbon stocks affected by mountain pine beetles in Idaho. Environ Res Lett 7:045702.

Bright BC, Hicke JA, Meddens AJ. 2013. Effects of bark beetlecaused tree mortality on biogeochemical and biogeophysical MODIS products. J Geophys Res Biogeosci 118:974-82.

Campbell J, Donato D, Azuma D, Law B. 2007. Pyrogenic carbon emission from a large wildfire in Oregon, United States. J Geophys Res 112:G04014.

Chapin FSIII, Woodwell GM, Randerson JT, Rastetter EB, Lovett GM, Baldocchi DD, Clark DA, Harmon ME, Schimel DS, Valentini R. 2006. Reconciling carbon-cycle concepts, terminology, and methods. Ecosystems 9:1041-50.

Coats R. 2010. Climate change in the Tahoe basin: regional trends, impacts and drivers. Clim Change 102:435-66.

Coats R, Costa-Cabral M, Riverson J, Reuter J, Sahoo G, Schladow G, Wolfe B. 2013. Projected 21st century trends in hydroclimatology of the Tahoe basin. Clim Change 116:5169.

Cole WE, Amman GD. 1980. Mountain pine beetle dynamics in lodgepole pine forests, Part 1: course of an infection. USFS General Technical Report INT.89.

Connell JH, Tracey J, Webb LJ. 1984. Compensatory recruitment, growth, and mortality as factors maintaining rain forest tree diversity. Ecol Monogr 54:142-64.

Creeden EP, Hicke JA, Buotte PC. 2014. Climate, weather, and recent mountain pine beetle outbreaks in the western United States. For Ecol Manage 312:239-51.

Díaz S, Lavorel S, de Bello F, Quétier F, Grigulis K, Robson TM. 2007. Incorporating plant functional diversity effects in ecosystem service assessments. Proc Natl Acad Sci 104:20684-9.

Dobrowski S, Greenberg J, Ustin S. 2005. Tahoe Basin existing vegetation map v. 4.1. Ecol Model 192:126-42.

Dolanc CR, Safford HD, Dobrowski SZ, Thorne JH. 2014. Twentieth century shifts in abundance and composition of vegetation types of the Sierra Nevada, CA, US. Appl Veg Sci 17:442-55.

Earles JM, North MP, Hurteau MD. 2014. Wildfire and drought dynamics destabilize carbon stores of fire-suppressed forests. Ecol Appl 24:732-40.
Edburg SL, Hicke JA, Brooks PD, Pendall EG, Ewers BE, Norton U, Gochis D, Gutmann ED, Meddens AJ. 2012. Cascading impacts of bark beetle-caused tree mortality on coupled biogeophysical and biogeochemical processes. Front Ecol Environ 10:416-24.

Egan JM, Jacobi WR, Negron JF, Smith SL, Cluck DR. 2010. Forest thinning and subsequent bark beetle-caused mortality in Northeastern California. For Ecol Manage 260:1832-42.

Egan JM, Sloughter JM, Cardoso T, Trainor P, Wu K, Safford H, Fournier D. 2016. Multi-temporal ecological analysis of Jeffrey pine beetle outbreak dynamics within the Lake Tahoe Basin. Popul Ecol 58:1-22.

Ferrell G, Otrosina W, Demars C Jr. 1994. Predicting susceptibility of white fir during a drought-associated outbreak of the fir engraver, Scolytus ventralis, in California. Can J For Res 24:302-5.

Fettig CJ, Klepzig KD, Billings RF, Munson AS, Nebeker TE, Negrón JF, Nowak JT. 2007. The effectiveness of vegetation management practices for prevention and control of bark beetle infestations in coniferous forests of the western and southern United States. For Ecol Manage 238:24-53.

Fettig CJ, McKelvey SR, Cluck DR, Smith SL, Otrosina WJ. 2010. Effects of prescribed fire and season of burn on direct and indirect levels of tree mortality in ponderosa and Jeffrey pine forests in California, USA. For Ecol Manage 260:207-18.

Forestry Canada Fire Danger Group 1992. Development and structure of the Canadian Forest Fire Behavior Prediction System. Forestry Canada, Science and Sustainable Development Directorate, Information Report ST-X-3, Ottawa, Ontario, Canada.

Franklin JF, Spies TA, Van Pelt R, Carey AB, Thornburgh DA, Berg DR, Lindenmayer DB, Harmon ME, Shaw DC, Bible K. 2002. Disturbances and structural development of natural forest ecosystems with silvicultural implications, using Douglas-fir forests as an example. For Ecol Manage 155:399-423.

Ghimire B, Williams CA, Collatz GJ, Vanderhoof ME, Rogan J, Kulakowski D, Masek JG. 2015. Large carbon release legacy from bark beetle outbreaks across western United States. Glob Change Biol 21:3087-101.

Guarín A, Taylor AH. 2005. Drought triggered tree mortality in mixed conifer forests in Yosemite National Park, California, USA. For Ecol Manage 218:229-44.

Harvey BJ, Donato DC, Turner MG. 2014. Recent mountain pine beetle outbreaks, wildfire severity, and postfire tree regeneration in the US Northern Rockies. Proc Natl Acad Sci 111:15120-5.

Hebertson EG, Jenkins MJ. 2008. Climate factors associated with historic spruce beetle (Coleoptera: Curculionidae) outbreaks in Utah and Colorado. Environ Entomol 37:281-92.

Hicke JA, Johnson MC, Hayes JL, Preisler HK. 2012a. Effects of bark beetle-caused tree mortality on wildfire. For Ecol Manage 271:81-90.

Hicke JA, Allen CD, Desai AR, Dietze MC, Hall RJ, Kashian DM, Moore D, Raffa KF, Sturrock RM, Vogelmann J. 2012b. Effects of biotic disturbances on forest carbon cycling in the United States and Canada. Glob Change Biol 18:7-34.

Hicke JA, Logan JA, Powell J, Ojima DS. 2006. Changing temperatures influence suitability for modeled mountain pine beetle (Dendroctonus ponderosae) outbreaks in the western United States. J Geophys Re Biogeosci 2005-2012:111.

Hood SM, Baker S, Sala A. 2016. Fortifying the forest: thinning and burning increase resistance to a bark beetle outbreak and promote forest resilience. Ecol Appl 26:1984-2000. 
Hurteau MD, Koch GW, Hungate BA. 2008. Carbon protection and fire risk reduction: toward a full accounting of forest carbon offsets. Front Ecol Environ 6:493-8.

Hurteau MD, Liang S, Martin KL, North MP, Koch GW, Hungate BA. 2016. Restoring forest structure and process stabilizes forest carbon in wildfire-prone southwestern ponderosa pine forests. Ecol Appl 26:382-91.

Jenkins MJ, Hebertson E, Page W, Jorgensen CA. 2008. Bark beetles, fuels, fire and implications for forest management in the Intermountain West. For Ecol Manage 254(1):16-34.

Klutsch JG, Negron JF, Costello SL, Rhoades CC, West DR, Popp J, Caissie R. 2009. Stand characteristics and downed woody debris accumulations associated with a mountain pine beetle (Dendroctonus ponderosae Hopkins) outbreak in Colorado. For Ecol Manage 258:641-9.

Kretchun AM, Scheller RM, Lucash MS, Clark KL, Hom J, Van Tuyl S. 2014. Predicted effects of gypsy moth defoliation and climate change on forest carbon dynamics in the New Jersey Pine Barrens. PLoS ONE 9:e102531.

Kretchun AM, Loudermilk EL, Scheller RM, Hurteau MS, Belmecheri S. 2016. Climate and bark beetle effects on forest productivity-linking dendroecology with forest landscape modeling. Can J For Res 46:1026-34.

Kurz WA, Dymond CC, Stinson G, Rampley GJ, Neilson ET, Carroll AL, Ebata T, Safranyik L. 2008. Mountain pine beetle and forest carbon feedback to climate change. Nature 452:987-90.

Loudermilk EL, Scheller RM, Weisberg PJ, Kretchun AM. 2016. Bending the carbon curve: fire management for carbon resilience under climate change. Landsc Ecol 32:1-12.

Loudermilk EL, Scheller RM, Weisberg PJ, Yang J, Dilts TE, Karam SL, Skinner C. 2013. Carbon dynamics in the future forest: the importance of long-term successional legacy and climate-fire interactions. Glob Change Biol 19:3502-15.

Loudermilk EL, Stanton A, Scheller RM, Dilts TE, Weisberg PJ, Skinner C, Yang J. 2014. Effectiveness of fuel treatments for mitigating wildfire risk and sequestering forest carbon: a case study in the Lake Tahoe Basin. For Ecol Manage 323:114-25.

Lucash MS, Scheller RM, Kretchun AM, Clark K, Hom J. 2014. Impacts of climate change and fire on long-term nitrogen cycling and forest productivity in the New Jersey Pine Barrens. Can J For Res 44:402-12.

Lynch HJ, Renkin RA, Crabtree RL, Moorcroft PR. 2006. The influence of previous mountain pine beetle (Dendroctonus ponderosae) activity on the 1988 Yellowstone fires. Ecosystems 9:1318-27.

Mattson WJ, Haack RA. 1987. The role of drought in outbreaks of plant-eating insects. Bioscience 37:110-18.

Meddens AJ, Hicke JA, Ferguson CA. 2012. Spatiotemporal patterns of observed bark beetle-caused tree mortality in British Columbia and the western United States. Ecol Appl 22:1876-91

Miller JD, Safford HD, Crimmins M, Thode AE. 2009. Quantitative Evidence for Increasing Forest Fire Severity in the Sierra Nevada and Southern Cascade Mountains, California and Nevada, USA. Ecosystems 12:16-32.

Mladenoff DJ. 2004. LANDIS and forest landscape models. Ecol Model 180:7-19.

Nagel TA, Taylor AH. 2005. Fire and persistence of montane chaparral in mixed conifer forest landscapes in the northern Sierra Nevada, Lake Tahoe Basin, California, USA 1. J Torrey Bot Soc 132:442-57.
Negron JF, McMillin JD, Anhold JA, Coulson D. 2009. Bark beetle-caused mortality in a drought-affected ponderosa pine landscape in Arizona, USA. For Ecol Manage 257:1353-62.

Negrón JF, Popp JB. 2004. Probability of ponderosa pine infestation by mountain pine beetle in the Colorado Front Range. For Ecol Manage 191:17-27.

North MP, Hurteau MD. 2011. High-severity wildfire effects on carbon stocks and emissions in fuels treated and untreated forest. For Ecol Manage 261:1115-20.

Palmer WC. 1965. Meteorological drought. Washington: US Department of Commerce, Weather Bureau.

Parton WJ, Anderson DW, Cole CV, Steward JWB. 1983. Simulation of soil organic matter formation and mineralization in semiarid agroecosystems. In Lowrance RR, Todd RL, Asmussen LE, Leonard RA, Eds. Nutrient cycling in agricultural ecosystems. The University of Georgia, College of Agriculture Experiment Stations, Athens GA.

Parton WJ, Ojima DS, Cole CV, Schimel DS. 1994. A general model for soil organic matters dynamics: sensitivity to litter chemistry, texture and management. Quantitative modeling of soil forming processes: proceedings of a symposium sponsored by Divisions S-5 and S-9 of the Soil Science Society of America. Soil Science Society of America, Minneapolis, MN, pp 147-67.

Peterson DL, Vose JM, Patel-Weynand T. 2014. Climate change and United States Forests. Dordrecht: Springer.

Raffa KF, Aukema BH, Bentz BJ, Carroll AL, Hicke JA, Turner MG, Romme WH. 2008. Cross-scale drivers of natural disturbances prone to anthropogenic amplification: the dynamics of bark beetle eruptions. Bioscience 58:501-17.

Scheller RM, Domingo JB, Sturtevant BR, Williams JS, Rudy A, Gustafson EJ, Mladenoff DJ. 2007. Design, development, and application of LANDIS-II, a spatial landscape simulation model with flexible spatial and temporal resolution. Ecol Model 201:409-19.

Scheller RM, Hua D, Bolstad PV, Birdsey RA, Mladenoff DJ. 2011. The effects of forest harvest intensity in combination with wind disturbance on carbon dynamics in Lake States mesic forests. Ecol Model 222:144-53.

Schmidt DA, Taylor AH, Skinner CN. 2008. The influence of fuels treatment and landscape arrangement on simulated fire behavior, Southern Cascade range, California. For Ecol Manage 255:3170-84.

Schwilk DW, Knapp EE, Ferrenberg SM, Keeley JE, Capiro AC. 2006. Tree mortality from fire and bark beetles following early and late season prescribed fires in a Sierra Nevada mixedconifer forest. For Ecol Manage 232(36):45.

Smithwick EAH, Harmon ME, Domingo JB. 2007. Changing temporal patterns of forest carbon stores and net ecosystem carbon balance: the stand to landscape transformation. Landsc Ecol 22:77-94.

Stephens SL, Moghaddas JJ, Edminster C, Fiedler CD, Haase S, Harrington M, Keeley JE, Knapp EE, McIver JD, Metlen K. 2009. Fire treatment effects on vegetation structure, fuels, and potential fire severity in western US forests. Ecol Appl 19:30520.

Sturtevant BR, Gustafson EJ, Li W, He HS. 2004. Modeling biological disturbances in LANDIS: A module description and demonstration using spruce budworm. Ecol Model 180:15374 .

Sturtevant BR, Scheller RM, Miranda RM, Shinneman D. 2009. Simulating dynamic and mixed-severity fire regimes: a pro- 
cess-based fire extension for LANDIS-II. Ecol Model 220:3380-93.

Syphard AD, Scheller RM, Ward BC, Spencer WD, Strittholt JR. 2011. Simulating landscape-scale effects of fuels treatments in the Sierra Nevada, California. Int J Fire Manag 20:364-83.

Taylor AH. 2004. Identifying forest reference conditions on early cut-over lands, Lake Tahoe Basin, USA. Ecol Appl 14:1903-20.

van Mantgem PJ, Stephenson NL, Byrne JC, Daniels LD, Franklin JF, Fule PZ, Harmon ME, Larson AJ, Smith JM, Taylor AH, Veblen TT. 2009. Widespread increase of tree mortality rates in the western United States. Science 323:521-4.

Walker R, Fecko R, Frederick W, Johnson D, Miller W. 2007. Forest health impacts of bark beetles, dwarf mistletoe, and blister rust in a Lake Tahoe Basin mixed conifer stand. West $\mathrm{N}$ Am Nat 67:562-71.

Ward NL, Masters GJ. 2007. Linking climate change and species invasion: an illustration using insect herbivores. Glob Change Biol 13:1605-15.

Westerling A, Bryant B, Preisler H, Holmes T, Hidalgo H, Das T, Shrestha S. 2011. Climate change and growth scenarios for California wildfire. Clim Change 109:445-63.
Westerling AL. 2016. Increasing western US forest wildfire activity: sensitivity to changes in the timing of spring. Phil Trans R Soc B 371:20150178.

Westerling AL, Hidalgo HG, Cayan DR, Swetnam TW. 2006. Warming and earlier spring increase Western US Forest Wildfire Activity. Science 313:940-3.

Williams AP, Allen CD, Macalady AK, Griffin D, Woodhouse CA, Meko DM, Swetnam TW, Rauscher SA, Seager R, GrissinoMayer HD. 2013. Temperature as a potent driver of regional forest drought stress and tree mortality. Nature Climate Change 3:292-7.

Williams CA, Collatz GJ, Masek JG, Huang C, Goward S. 2014. Impacts of disturbance history on forest carbon stocks and fluxes: merging satellite disturbance mapping with forest inventory data in a carbon cycle model framework. Remote Sensing Environ 151:57-71.

Williams CA, Gu H, MacLean R, Masek JG, Collatz GJ. 2016. Disturbance and the carbon balance of US forests: a quantitative review of impacts from harvests, fires, insects, and droughts. Global Planet Change 143:66-80. 